\title{
Taman Baca Anak: Pengembangan Literasi Kearifan Lokal
}

\section{Ratna Wijayanti Daniar Paramita}

\author{
STIE Widya Gama Lumajang \\ pradnyataj@gmail.com
}

\begin{abstract}
ABSTRAK
Taman bacaan anak ini merupakan taman bacaan yang didirikan dengan sasaran anakanak usia pra sekolah dan usia TK dan lokasi taman bacaan inipun berada pada lokasi sekolah Paud dan posyandu. Keberadaan taman bacaan ini cukup mendapat respon dan diminati anakanak baik pada buku-buku cerita anak dan permainan eduktif karena sebagai sesuatu yang tidak mereka miliki di rumah. Sehingga keberadaan taman bacaan ini tidak hanya sebagai sarana belajar tetapi juga sarana bermain anak-anak. Permasalahan yang dihadapi pada taman bacaan ini adalah minimnya koleksi buku-buku, sarana dan prasarana yang belum memadai serta manajemen pengelolaan taman bacaan yang masih rendah. Target yang akan dicapai di dalam pengabdian bagi masyarakat ini adalah berupa pencapaian tujuan umum kegiatan pengabdian masyarakat yaitu untuk pengembangan taman bacaan anak. Untuk mencapai tujuan tersebut rencana kegiatan ini adalah berupa: memberikan penyediaan sarana dan prasarana meliputi penambahan koleksi buku-buku, penyediaan rak tempat buku, penyediaan sarana permaianan edukatif, desain tempat untuk memberikan kenyamanan pada anak-anak ketika berada di taman bacaan tersebut. Disamping itu juga memberikan pelatihan manajemen terkait pengelolaan dan pemeliharaan buku-buku serta pelatihan penggunaan permainan edukatif. Diharapkan menjadi tempat pengembangan budaya literasi dengan tidak menghilangkan kearifan lokal.
\end{abstract}

\section{Kata Kunci: Taman bacaan, buku-buku, sarana permainan edukatif, belajar dan bermain}

\begin{abstract}
This children's reading park is a reading park that was set up targeting pre-school age children and kindergarten age and even the location of this reading park is at the location of the Paud and Posyandu schools. The existence of this reading park is quite a response and is of interest to children both in children's story books and eductive games because it is something they do not have at home. So that the existence of this reading park is not only a means of learning but also a means of children's play. The problem faced in this reading park is the lack of collections of books, inadequate facilities and infrastructure and low management of park management. The target to be achieved in this community service is the achievement of the general objectives of community service activities, namely for the development of children's reading parks. To achieve these objectives the plan of activities is in the form of: providing provision of facilities and infrastructure including the addition of a collection of books, provision of bookshelves, provision of educational play facilities, design of places to provide comfort for children while in the reading park. Besides that it also
\end{abstract}


provides management training related to the management and maintenance of books and training in the use of educational games. It is expected to be a place for developing literacy culture by not eliminating local wisdom.

\section{Keywords: reading gardens, books, means of educational games, learning and playing}

\section{PENDAHULUAN}

\section{A. Analisis Situasi}

Dunia anak adalah dunia bermain, melalui bermain anak memperoleh pelajaran yang mengandung aspek perkembangan kognitif, sosial, emosi dan perkembangan fisik. Melalui kegiatan bermain dengan berbagai permainan anak dirangsang untuk berkembang secara umum baik perkembangan berpiikir, emosi maupun sosial.

Pendidikan pada dasarnya tidak hanya terbatas dan tersekat pada pola pendidikan di sekolah. Mendidik pada hakekatnya adalah kegiatan yang dapat memberikan motivasi dan penyediaan sumber-sumber belajar. Salah satu sumber belajar yang banyak dikenal di masyarakat adalah perpustakaan. Layaknya perpustakaan, taman bacaan masyarakat menyediakan bahan pustaka yang sangat berguna bagi pelaksanaan dan peningkatan proses belajar mengajar juga mengembangkan nilai-nilai dan sifat demokratis, ekonomis, kritis, kooperatif, kreatif dan disiplin pribadi, nilai-nilai dan sikap yang dipandang terpuji dalam pergaulan masyarakat.

Taman bacaan masyarakat (TBM) masih sangat sedikit. Idealnya setiap desa memiliki taman macaan masyarakat, karena taman bacaan sangat penting untuk meningkatkan minat baca masyarakat, khususnya anak-anak usia sekolah. Saat ini di Indonesia hanya ada 6.000 TMB, padahal jumlah desa di Indonesia sekitar 72.000 desa. Kecamatan Pasrujambe merupakan salah satu dari 21 Kecamatan yang ada di Kabupaten Lumajang. Luas Kecamatan Pasrujambe adalah $97,30 \mathrm{Km}^{2}$ dengan jumlah penduduk sebesar 37.724 jiwa yang tersebar pada 7 Desa.

Taman bacaan masyarakat yang ada di desa Pagowan Kecamatan Pasrujambe Kabupaten Lumajang yang merupakan satu-satunya taman bacaan di kecamatan ini, awalnya didirikan oleh mahasiswa STIE Widya Gama Lumajang yang dilaksanakan pada program kerja KKN. Taman bacaan ini lebih dikhususkan untuk anak-anak usia pra sekola,TK dan SD dan diberi nama TAMAN BACA ANAK “RUMAH CERDAS”.

Taman bacaan "Rumah Cerdas" ini bertujuan untuk membangkitkan semangat belajar, kegemaran dan minat baca, membangkitkan minat terhadap hal-hal baru melalui buku-buku dan untuk mengasah motoriknya melalui permainan-permainan edukatif. 
Selanjutnya Taman bacaan "Rumah Cerdas" juga bertujuan mendidik anak-anak dalam hal kerapian, ketertiban disiplin dan tanggung jawab menggunakan fasilitas yang tersedia.

Sedangkan fungsi Taman bacaan "Rumah Cerdas" diusahakan dapat menjadi perlengkapan pendidikan yang merupakan bagian terpadu dalam sistem kurikulum pendidikan yang mempunyai fungsi untuk :

1) Memujudkan suatu wadah pengetahuan dengan administrasi dan organisasi yang sesuai sehingga memudahkan penggunaannya

2) Menyediakan sumber-sumber rujukan yang tepat guna unuk kegiatan konsultasi bagi pembaca

3) Menyediakan bahan-bahan yang bermanfaat bagi kegiatan rekreatif yang berkaitan dengan bidang budaya dan mengembangkan daya kreatif

4) Melaksanakan layanan taman bacaan yang sederhana, mudah dan menarik sehingga pembaca (khususnya anak-anak) tertarik dan dapat terbiasa dalam menggunakan fasilitas taman bacaan.

Sasaran yang akan dicapai dengan adanya taman bacaan ini adalah terwujudnya taman bacaan yang dapat menjadi pusat kegiatan belajar, membaca dan bermain. Di samping itu diharapkan dapat membantu pengembangan bakat dan minat anak serta dapat menyediakan bahan pustaka dalam jumlah dan mutu yang memadai. Sasaran yang lebih penting lagi adalah terbinanya semangat belajar, gemar membaca, biasa membaca, terampil, merasa perlu selalu membaca dam meningkatkan gairah belajar dan mampu belajar secara mandiri, sehingga tercapai cita-cita pendidikan anak.

Gagasan pendirian Taman bacaan "Rumah Cerdas" adalah kebutuhan Paud terkait dengan buku-buku cerita bergambar, pengenalan angka dan abjad dan buku-buku mewarnai yang ketersediaan di Paud sangat terbatas. Demikian juga dengan alat permainan edukatif. Demikian juga dengan taman posyandu yang keberadaannya diharapkan dapat lebih menarik bagi orang tua balita dan balita sendiri dengan penyediaan alat-alat permainan.

\section{B. Permasalahan Mitra}

Pada dasarnya permasalahan yang dihadapi mitra sangat beragam dan saling terkait antara permasalahan yang satu dengan lainnya, namun permasalahan yang disampaiakan disini adalah permasalahan yang terkait dengan pendirian Taman bacaan "Rumah Cerdas". Permasalahan Berdasarkan hasil identifikasi dan analisis situasi didapatkan beberapa permasalahan yang perlu segera dicari solusi alternatifnya yaitu : 
1. Berdasarkan pengamatan dilokasi bahwa kondisi sekolah Paud "harapan Jaya" belumlah sempurna jika dibandingkan dengan keberadaan standarisasi sebuah sekolah Paud. Ruangan yang masih terbuka, hanya ada dinding setinggi 1 (satu) meter yang membatasi bahwa ini adalah sebuah ruangan, belum ada kursi sehingga mereka belajar hanya beralaskan karpet, meja yang tersedia adalah meja panjang (1 meja untuk 4-6 anak). Dari sisi buku dan alat bermain/ peraga pendidikan yang seharusnya dilengkapi dengan :

- Buku perpustakaan untuk guru.

- Buku perpustakaan untuk anak seperti buku-buku cerita bergambar, buku gambar seri dan lain-lain.

- Alat peraga dan alat bermain dikelas seperti puzzel, balok bangunan, pohon hitung, puzzel huruf, kotak merjan, papan geometris dan lain-lain.

Menilik hal tersebut maka Paud "Harapan Jaya" memang masih perlu mendapat perhatian demi cita-cita anak desa yang ingin pintar dan maju untuk sebuah cita-cita pendidikan.

2. Permasalahan fasilitas pada posyandu "Harapan Jaya" adalah masalah kurangnya fasilitas bermain yang berbentuk permainan edukatif. Dengan permainan edukatif yang ada kualitas maupun kemampuan motorik anak batita dan balita akan menjadi lebih terasah.

\section{Potensi dan Peluang Taman bacaan "Rumah Cerdas"}

Potensi dan peluang Taman bacaan "Rumah Cerdas" ini sangat prospektif. Penambahan sarana Taman Bacaan pada lokasi ini tentunya semakin meningkatkan peran Paud dan Posyandu dalam pengenalan dan menumbuhkembangkan budaya dan gemar membaca bagi anak.

Fakta menunjukkan bahwa saat ini dengan jumlah judul buku yang sangat terbatas (86 cerita anak, 8 buku cerita bergambar, 7 buku belajar berhitung, membaca, mengenal abjad dan pelajaran SD, 15 majalah anak) jumlah anak-anak yang berkunjung ke taman bacaan diluar jam sekolah berkisar antara 10-20 anak setiap harinya. Jumlah anak-anak balita yang memanfaatkan fasilitas permainan edukatif juga ada setiap harinya diluar jam kunjung posyandu dan jam kelas Paud. Permainan edukatif yang tersedia pada taman bacaan ini hanya berupa pazzle, kartu lambang bilangan, puzzle berbentuk jam dan lego yang masing-masing jenis APE hanya tersedia 1 buah. 
Jumlah anak-anak yang berkunjung ke taman bacaan jika dirata-rata maka adalah 6\%$8 \%$ dari jumlah anak-anak yang ada di desa tersebut. Jumlah tersebut memang masih relatif kecil, namun keberadaan taman bacaan tersebut mendapat respon positif dari anak-anak yang terbukti dengan selalu ada anak yang berkunjung setiap harinya. Baik untuk membaca buku maupun untuk melakukan permainan edukatif. Dengan pengembangan sarana yang ada di Taman bacaan "Rumah Cerdas" diharapkan akan semakin menarik minat anak-anak untuk belajar dan bermain di taman bacaan.

\section{Tujuan Kegiatan}

Tujuan kegiatan pengabdian bagi masyarakat yaitu untuk membangkitkan semangat belajar, kegemaran dan minat baca, membangkitkan minat terhadap hal-hal baru melalui buku-buku dan untuk mengasah motoriknya melalui permainan-permainan edukatif. Untuk mencapau tujuan tersebut rencana kegiatan ipteks bagi masyarakat ini adalah berupa:

1. Memberikan bantuan berupa sarana dan prasarana taman bacaan yang mendekati standart dari sebuah tamna bacaan dengan pemberian buku-buku koleksi, alat peraga secara lengkap mulai dari angka, huruf, bidang geometri serta permainan edukatif berupa mainan balok yang dibuat dari bahan kayu atau sejenisnya dengan beberapa bentuk dan warna yang jelas agar anak bisa mengerti warna. Memberikan sarana berupa kursi, almari dari kayu atau sejenisnya dan diberi cat warna agar menarik buat anak-anak.

2. Memberikan pelatihan dan pendampingan bagi pengelola taman bacaan baik manajemen pengelolaan maupun pengarsipan agar mampu mengelola taman bacaan dengan baik dengan membuat pengarsipan perpustakaan dengan kondisi dan lingkungan taman bacaan.

3. Memberikan pelatihan dan pendampingan manfaat dan cara penggunaan permainan edukatif (APE) agar dapat digunakan secara optimal.

\section{METODE PELAKSANAAN}

Kegiatan pengabdian ini disajikan sebagai penelitian kualitatif, yaitu dari data dan fakta yang diperoleh dalam penelitian ditarik kesimpulan dalam bentuk kalimat pernyataan serta hasil penelitian dapat memberikan gambaran tentang keadaan yang terjadi pada saat penelitian. Penelitian kualitatif ini menyajikan data yang diperoleh secara lebih lengkap, lebih mendalam, kredibel, dan bermakna. Pendekatan yang digunakan dalam penelitian ini menggunakan pendekatan penelitian kualitatif dengan metode deskriptif. Pendekatan dilakukan dengan mendeskripsikan fenomena yang terjadi dalam masyarakat, mencoba 
membandingkan dan menemukan kondisi sosial yang sesungguhnya ada di dalam masyarakat, Permasalahan yang dibahas dalam penelitian ini tidak berhubungan dengan angka-angka, akan tetapi menyangkut pendeskripsian, penguraian dan penggambaran suatu masalah yang sedang terjadi. Penelitian deskriptif ini bertujuan agar peneliti dapat mendeskripsikan secara jelas dan terperinci tentang taman baca "Rumah Cerdas". Metode kualitatif utama yang digunakan adalah observasi dan tanya jawab secara langsung kepada masyarakat. Taman baca ini akan mengikuti kriteria, yaitu tersedianya ruangan untuk membaca, bercerita, menulis, bermain dan kegiatan sejenis yang dilengkapi dengan bahan bacaan dan sarana prasarana yang ada serta didukung oleh pengelola taman baca.

Secara kongkrit dari solusi yang ditawarkan diaplikasikan dalam beberapa bentuk kegiatan diantaranya :

a. Diskusi dan Penyamaan presepsi

Diskusi antara tim pelaksana dengan mitra untuk penyamaan presepsi dalam mencari solusi dari permasalahan yang telah teridentifikasi. Hal ini dimaksudkan untuk menghindari konflik apabila solusi alternatif diimplementasikan. Hal ini terkait juga dengan sarana dan prasarana yang dibutuhkan mitra.

b. Pengadaan dan pengelolaan sarana dan prasarana yang dibutuhkan untuk menunjang tercapainya tujuan kegiatan ini.

\section{HASIL DAN PEMBAHASAN}

Taman bacaan ini bearda pada lokasi Paud "Harapan Jaya" dan Posyandu Gerbang Mas Siaga "Harapan Jaya" di desa Pagowan Kecamatan Pasrujambe Kabupaten Lumajang. Secara lengkap kondisi eksisting kedua sekolah dapat dijelaskan sebagai berikut:

1. Paud "Harapan Jaya"

\section{a. Identitas sekolah}

$\begin{array}{ll}\text { Nama Sekolah } & : \text { Paud "Harapan jaya" } \\ \text { Kepala Sekolah } & : \text { Yuyun Indayani } \\ \text { Alamat } & : \text { Desa Pagowan Kecamatan Pasrujambe Kabupaten Lumajang } \\ \text { Tahun Berdiri } & : 2004 \\ \text { Akte Pendirian } & : 421.9 / 5.006 / 427.34 / 2010 \\ \text { Jumlah Guru } & : 3 \text { orang } \\ \text { Jumlah siswa } & : 23 \text { Siswa } \\ \text { Bangunan Sekolah } & : \text { Menumpang } \\ \text { Ruang Kelas } & : \text { 1 Ruang (Terbuka) } \\ \text { Ruang Kantor } & : 1 \text { Ruang } \\ \text { Penyelenggara } & : \text { TP PKK Desa Pagowan } \\ \text { Jumlah Meja } & : 4 \text { (ukuran } 100 \mathrm{~cm} \times 60 \mathrm{~cm}) \\ \text { Jumlah kursi } & : \text { Tidak ada }\end{array}$


Jumlah Rak buku : 1 Rak ukuran $300 \mathrm{~cm}$ x $60 \mathrm{~cm}$ dan 1 Rak ukuran $150 \mathrm{~cm}$ x60cm b. Manajemen Pengelolaan Sekolah

Visi Paud "Harapan Jaya" ini adalah terwujudnya anak usia dini yang cerdas, sehat, cerdas, ceria, beriman dan berbudi pekerti luhur dan bertingkah laku baik yang siap memasuki dunia pendidikan dasar dan jenang pendidikan selanjutnya.

Sekolah Paud “ Harapan Jaya” telah melakukan pengelolaan manajemen sekolah dengan dikendalikan oleh PKK desa. Sehingga secara struktur organisasi Paud tersebut dibawah kendali ibu kepala desa. Sedangkan pembagian pekerjaan pada masing-masing guru sudah diatur, hanya dalam pelaksanaan fungsi manajemennya masih kurang dapat berjalan secara lancar karena keterbatasan jumlah sumber dayanya.

\section{Pos Pelayanan Terpadu (Posyandu) Gerbang Mas "Harapan Jaya"}

\section{a. Identitas Posyandu}

Nama Kelompok : Posyandu Gerbang Mas Siaga“Harapan jaya”

Ketua Kelompok : Ibu Sutik
Alamat
: Desa Pagowan Kecamatan Pasrujambe Kabupaten Lumajang
Jumlah Pengurus : 6 orang
Jumlah anggota : 77 (bayi dan balita)

\section{b. Manajemen Pengelolaan}

Posyandu yang bertujuan untuk Deteksi Dini Tumbuh Kembang Balita. Kegiatan taman posyandu "Harapan Jaya" adalah pengembangan peran posyandu yang selama ini hanya melayani masalah kesehatan anak usia balita, mulai dari pemenuhan asupan gizi, perawatan, pengasuhan, kesejahteraan dan perlindungan saja. Balita yang datang, nantinya juga akan diedukasi sesuai perkembangan usia mereka. Ini mengintegrasikan pelayanan kesehatan dan pendidikan anak-anak balita, sehingga mereka juga akan mendapatkan pendidikan disesuaikan usianya.

Dalam melaksanakan program ini mitra sangat mendukung dan memberikan partisipasi dalam bentuk:

a. Bersedia berdiskusi dan berpartisipasi akatif bersama tim pelaksana dalam pelaksanaan program pelatihan dan pendampingan.

b. Ikut memberikan saran dan masukan dalam mendesain sarana dan prasarana.

c. Ikut serta dalam uji coba dan demonstrasi sarana dan prasarana yang dimiliki mitra. 
d. Menyiapkan tenaga kerja sebagai tenaga pengelola.

e. Bersedia bekerjasama secara berkelanjutan.

Pada pengembangan aspek manajemen difokuskan pada pengembangan tenaga pengelola dalam peningkatan mutu pengelolaan taman bacaan melalui :

a. Pelatihan dan Pendampingan manajemen pengelolaan dan pendampingan dalam membuat pengkodean buku, pengarsipan, pembuatan kartu anggota dan kartu pinjaman buku.

b. Memberikan pelatihan dalam mengoptimalkan penggunaan permainan edukatif serta manfaatnya. Setidaknya terdapat 10 hal yang harus dipahami tentang pentingnya permainan edukatif bagi anak:

- dapat membantu anak dalam mengembangkan dirinya.

- mampu meningkatkan kemampuan berkomunikasi bagi anak.

- mampu membantu anak dalam menciptakan hal baru atau memberi inovasi pada suatu permainan.

- permainan edukatif mampu meningkatkan cara berpikir pada anak.

- mampu meningkatkan perasaan anak.

- mampu meningkatkan rasa percaya diri pada anak.

- mampu merangsang imajinasi pada anak.

- dapat melatih kemampuan bahasa pada anak

- dapat membentuk moralitas anak.

- dapat mengembangkan rasa sosialisasi pada anak.

Sedangkan pengembangan dan pengadaaan sarana yang menunjang kegiatan taman baca "Rumah Cerdas" dilakukan antara lain seperti pada Tabel 1.

Tabel. 1

Pengadan Sarana Taman Baca "Rumah Cerdas"

\begin{tabular}{|l|l|l|}
\hline No & Sarana / Prasarana & \multicolumn{1}{c|}{ Keterangan } \\
\hline 1. &
\end{tabular}




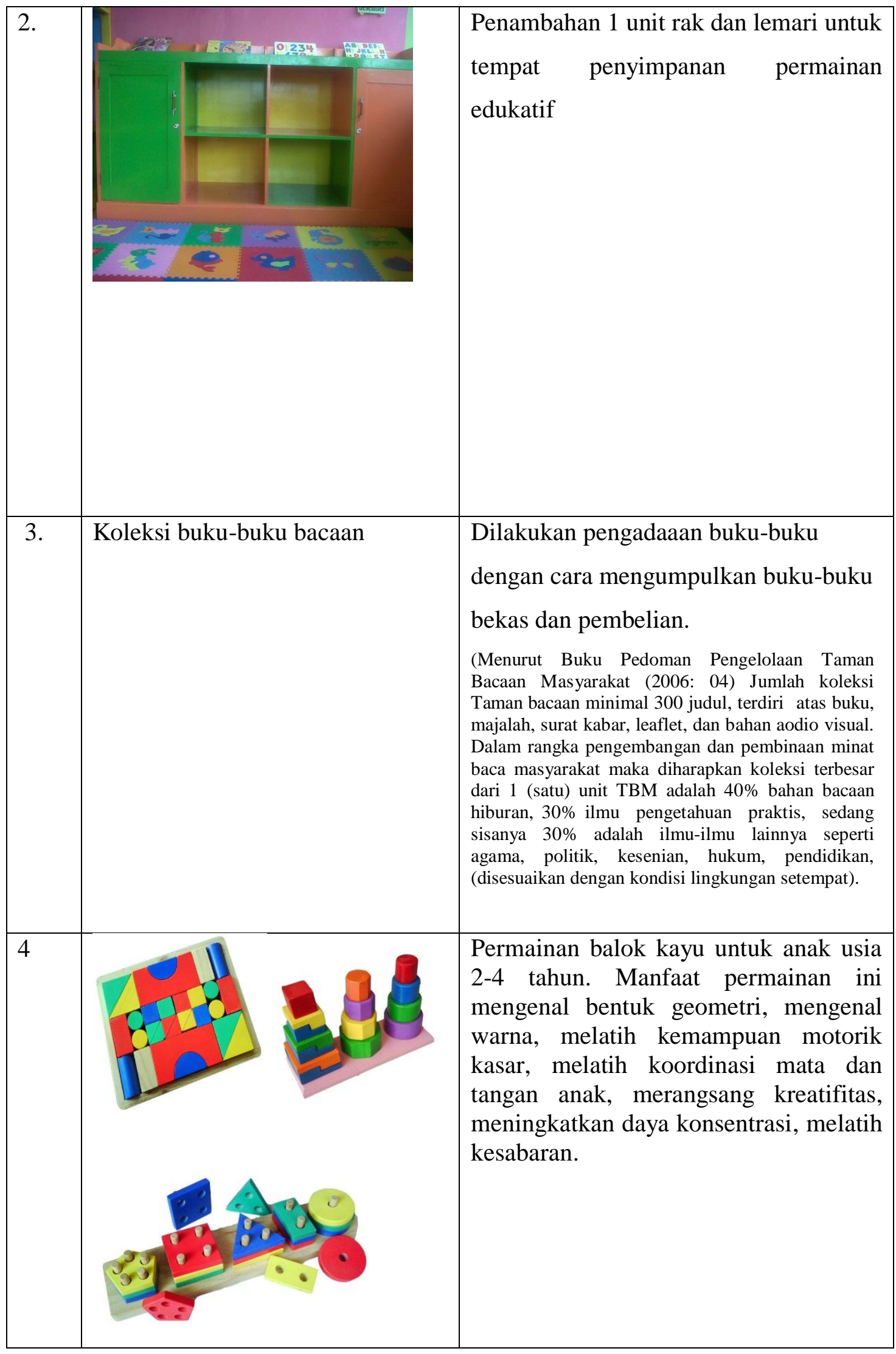




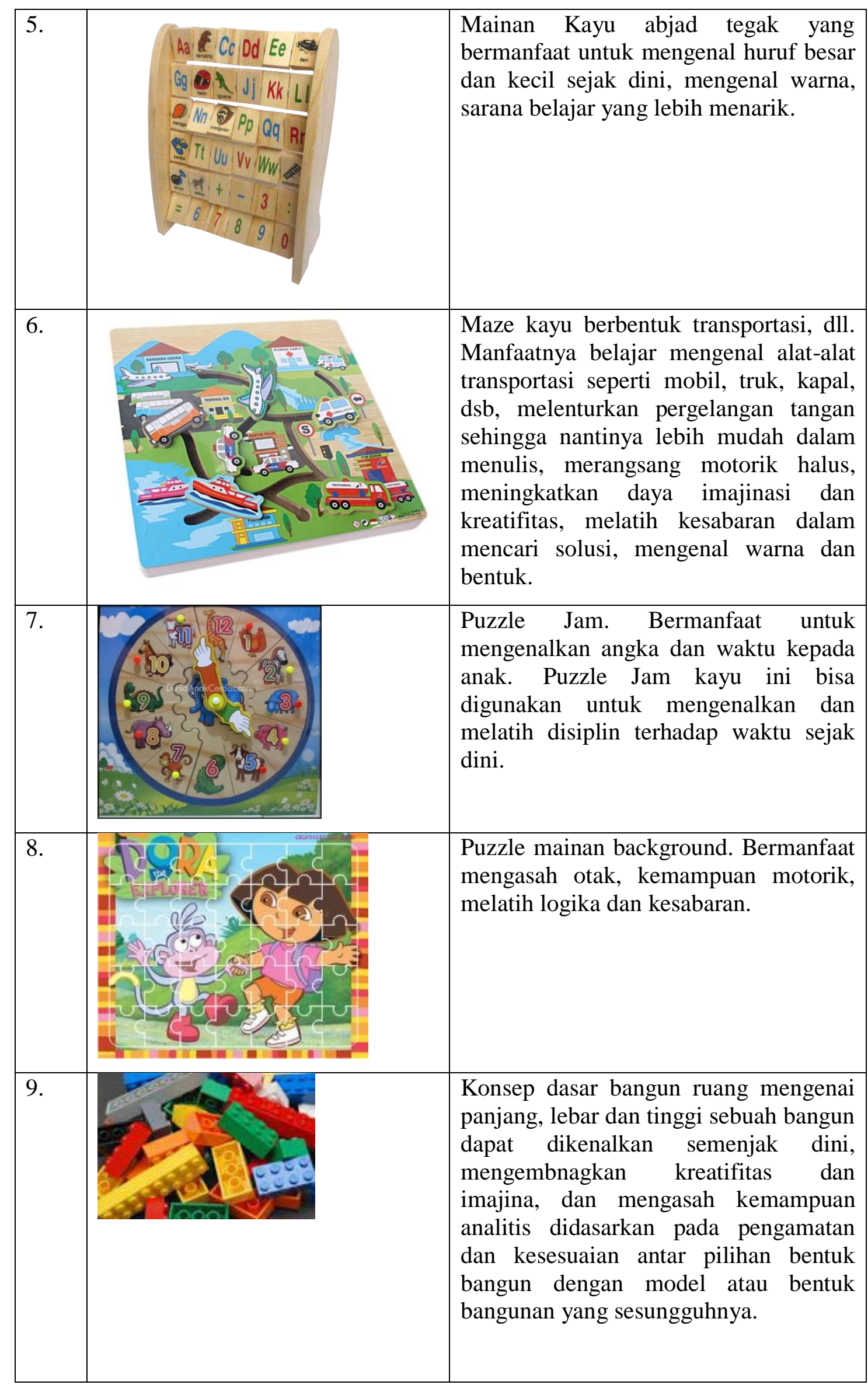




\begin{tabular}{|l|l|l|}
\hline 10. & & \\
\hline & & $\begin{array}{l}\text { Mainan bowling untuk batita. Mainan } \\
\text { ini bermanfaat untuk mengasah motorik } \\
\text { kasar dan melatih ketangkasan. }\end{array}$ \\
\hline
\end{tabular}

Penjelasan:

a. Pengadaan disesuaikan dengan kebutuhan Paud, dimana dalam belajar siswa dibuat perkelompok sehingga menjadi 4-5 kelompok. Tidak dilakukan penambahan pada meja karena lokal kelas tidak memungkinkan untuk menampung meja dan kursi sesuai kebutuhan.

b. Dibutuhkan 1 almari untuk menyimpan arsip administrasi, seperangkat komputer dan printer serta kursi dan meja komputer.

c. Pengadaan sarana dan prasarana tersebut akan dimanfaatkan oleh Paud dalan melaksanakan proses pembelajaran, oleh taman posyandu dan tentunya terlebih lagi bagi taman bacaan "Rumah Cerdas"
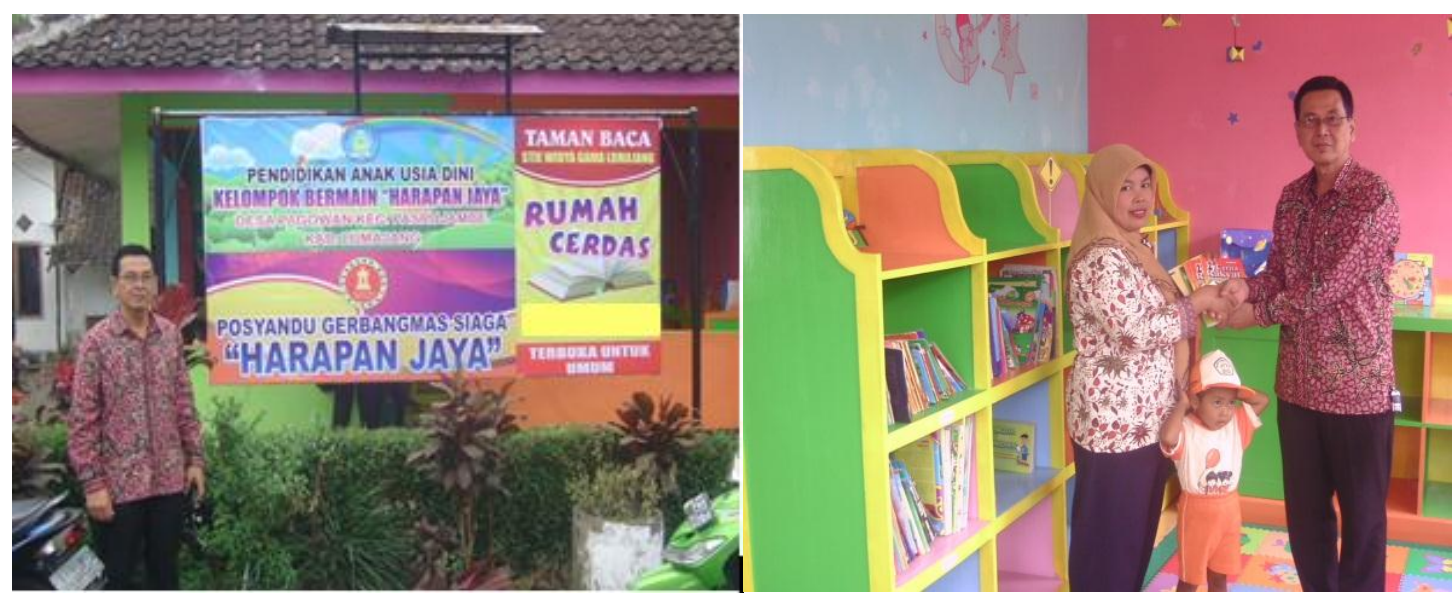

Gambar 1. Serah Terima Taman Bacaan "Rumah Sehat" dari STIE Widya Gama Lumajang 


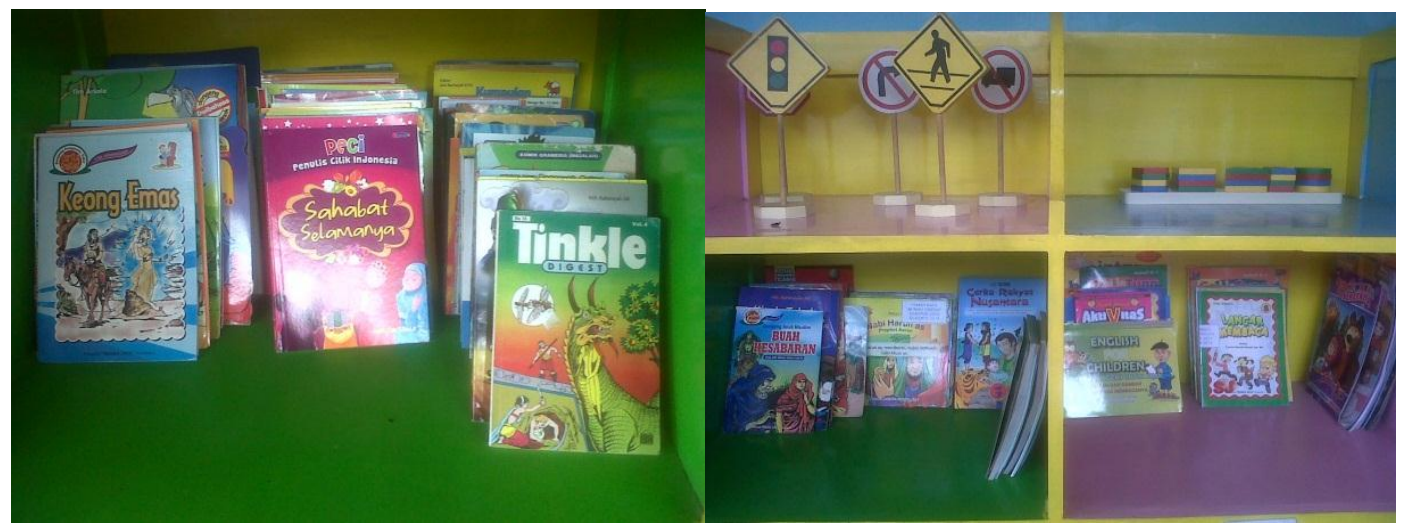

Gambar 2. Koleksi buku-buku Taman Bacaan "Rumah Cerdas"

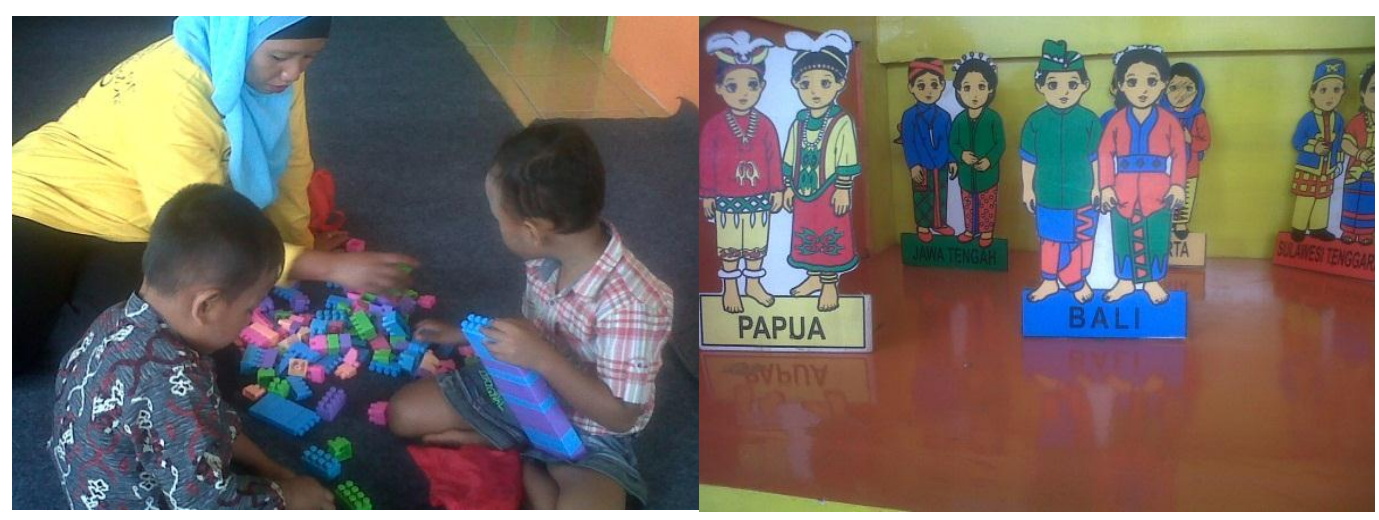

Gambar 3. Koleksi Permainan dan Peraga Taman Bacaan "Rumah Cerdas”

\section{KESIMPULAN}

Kehadiran taman baca sebagai pendidikan non formal ditingkat pedesaan menjadi salah satu solusi yang murah dan merakyat untuk kepanjangan tangan pemerintah dalam melaksanakan cita-cita pembangunan secara umumnya. Maka dari itu, keberadaan taman baca anak atau masyarakat sebagai sebuah wadah non-formal untuk menjawab kebutuhan pendidikan, sangat dibutuhkan, khususnya bagi anakusia dini sebagai generasi muda yang kelak akan berperan dalam pembangunan desanya. Sebuah wadah yang juga berfungsi untuk memantik potensi-potensi kreatif yang terpendam. Sebuah wadah yang menyediakan akses pembelajaran yang mudah, murah, dan merakyat. Taman baca "Rumah Cerdas" diharapkan menjadi tempat pengembangan budaya literasi dengan tidak menghilangkan kearifan lokal. 


\section{DAFTAR PUSTAKA}

Direktorat Penelitian dan Pengabdian kepada Masyarakat, DIKTI, 2013. Panduan Pelaksanaan Penelitian Dan Pengabdian Kepada Masyarakat Di Perguruan Tinggi Edisi IX.

Dirjen Paun, Nonformal dan Informal, (2013), "Petunjuk Teknis Penyelenggaraan Paud" Direktorat Pendidikan Usia Dini, Kementerian Pendidikan dan Kebudayaan.

Direktorat pendidikan masyarakat, pedoman pengelolaan taman bacaan masyarakat Jakarta: Direktorat jendral pendidikan luar sekolah departemen pendidikan nasional, 2006

Martuti, A.2008. Mengelola PAUD dengan Aneka Permainan Meraih Kecerdasan Majemuk. Yogyakarta: Kreasi Wacana.

Sutarno NS, Perpustakaan dan masyarakat, akarta, yayasan obor indonesia, 2003

Simbolon, Tony, pengembangan budaya baca melalui taman bacaan masyarakat, Jakarta, PT Ryan eka mandiri, 2007 